\title{
焼結 $\mathrm{Mn}-\mathrm{Bi}$ 永久磁石の磁気特性と耐酸化性について
}

\section{永 倉 充* 荒井 喴 彦*}

Mitsuru Nagakura and Shigehiko Arai : On the Magnetic Properties and Oxidation Behavior of Sintered $\mathrm{Mn}-\mathrm{Bi}$ Magnet. The $\mathrm{MnBi}$ maznet poses a problem in its practical use because of the tendency due to oxidation, in spite of its excellent magnetic properties. In the present study samples were prepared by firing compacts of $\mathrm{Mn}$ and $\mathrm{Bi}$ powders in stoichiometrical composition ( $\mathrm{Mn}: \mathrm{Bi}=3: 2$ ) at $260^{\circ} \mathrm{C}$ for $20 \mathrm{hr}$, pressing the compound with and without orienting magnetic field and sintering the compact at $250^{\circ} \mathrm{C}$ to $350^{\circ} \mathrm{C}$ for $3 \mathrm{hr}$. Then the effects of sintering were investigated on their magnetic properties and their oxidation behavior of sintered magnets with and without $\mathrm{Cu}$ plating. The results may be summarized as follows :

(1) The Magnetic properties were improved by sintering; especially, the effects of sintering on magnetic properties of anisotropic specimens were very distinat iz $B s, B r, B r / B s$ and $(B H)$ max., etc. It was confirmed that fine particles of the compound grew in the field direction applied during pressing.

(2) The effect of sintering on the oxidation behavior is clear and also the Cu-plated samples can perfectly prevent oxiđation.

$$
\text { (Received February 18, 1969) }
$$

\section{I. 舶}

現在, 永久磁石材料として，アルニュ系西るいは，Baフェライト采磁石がその二大主流を占めている。最近にな
つて MnBi, MnAl, Rare earth-Co 系を中心とした高い結 晶異方性定数を持つ金属間化合物磁性材料が研究の対象と

* 明治大学工学部 (Faculty of Engineering, Meiji University, Kawasaki) 
して，また実用化という点より注目を集めてきている。 金属間化合物 MnBi が強磁性を有することは 1904 年, Heusler (1)により発表された。甹の後, Bekier ${ }^{(2)} や S i e b e^{(3)}$ は MnBi 系の状態図を定め, 化学量論的な組成で $\mathrm{Mn}: \mathrm{Bi}$ $=1: 1$ に強磁性相のあることを報告している。皇の後これ 関する数多くの研究がなされているがとくに Guillaud (4) は1943 年に結晶異方性定数を室温で測定し $K: 11.2 \times 10^{6}$ $\mathrm{erg} / \mathrm{cm}^{3}$ の値を得て和り，同時飞 $3.3 \mu$ の粒子で ${ }_{1} H_{C}$ ： 12000 Oe といら值を得ている.

1952 年 Adams ら ${ }^{(5)}$ が Bi と Mn を不活性ガス中で溶解 し，複雑な冷却技術を用いて MnBi の化学量論的な化合物 作成法およびその磁気特性の報告がある，さらにこの合金 について基本的磁気特性や磁区構造についての報告がなさ れている(6) (12).

最近，金子ら ${ }^{(13)}$ はX線回折を用い強磁性相が $\mathrm{Mn}_{3} \mathrm{Bi}_{2}$ で あることを報告している。 また牧野ら ${ }^{(14)}$ によつて粉末冾 金法による化合物作成法ならびにそれらを樹脂中で成形し た場合の磁気特珄について報告がなされている。

著者らは, $\mathrm{MnBi}$ 系化合物磁石を化学量論的な組成で $\mathrm{Mn}: \mathrm{Bi}=3: 2$ の点を取り上げ，粉末冶金法により長時間 の焼結をして化合物を作成し，これら化合物を再び粉末に し等方的におよび磁界中で成形して尭結するという2段の 焼結により試料を作成し，その磁気特性および酎酸化性の 諸問題につき実験を試みたので報告する。

\section{II. 実験 方 法}

\section{Mn-Bi 化合物の反応}

実験江用いた原料は電解マンガンおよびビスマスであ り，その純度はそれぞれ Mn 99.9\%，Bi 99.9\%である. Mn，Bi の両渚をそれぞれ鉄乳鉢で 100 mesh 以下に粉确 し,ざらにボールミル(湿式法)で50時間粉碎した。 得ら れた粉末を 200 mesh のふるいを通し，Mn，Bi の各くを 200 mesh 以下の粉末とした. これらの粉末を重量パーセン トで $\mathrm{Mn}: \mathrm{Bi}=28: 72$ の配合比で混合し, 成形压 $4 \mathrm{t} / \mathrm{cm}^{2}$ 。 直㺯 $10 \mathrm{~mm} \phi$, 高さ $10 \sim 15 \mathrm{~mm}$ の円柱状に成形して，Bi

(1) F.Heusler : Z.angew.Chem., 17 (1904), 260.

(2) E. Bekier : Int.Zeitsch.Metallogrphie, 7(1915), 83.

(3) Z.Siebe : Z.Allgen.Chem., 108 (1919), 161.

(4) C.Guillaud : Thesis Strasbourg, (1943).

(5) E.Adams et al : J.Appl.Phys., 23 (1952), 1207.

(6) R.R.Heikes : Phys.Rev., 99 (1955), 446.

(7) B.W.Roberts : Phys.Rev., 104 (1956) , 607.

(8) T.O.Paine, L.I.Mendelsohn and F.E.Luborsky : Electrical Engineering, 76 (1957), 851.

(9) E.V.Shtolts, Ya.S.Shur and G.S.Kandaurova: Phys. Met.and Metallog., 5(1957), No.3, 31.

(10) O.L. Boothby, et al : J.Appl.Phys., 29 (1958), 353.

(11) P.A.Alber and W.J.Carr, Jr. : J.Appl.Phys., 32 (1961), 201.

(12) B.W.Roberts and C.P.Bean : Phys. Rev., 96 (1954), 1494.

（13）金子，西沢，田中：本誌，26(1962)，71.

(14) 牧野, 鈴木：本誌, $24(1960), 24$.
の融点以下の $260^{\circ} \mathrm{C} て ゙ 20$ 時間, $\mathrm{Ar}$ 気流中で反応させ $\mathrm{Mn}-$ $\mathrm{Bi}$ 化合物を作成した，また異方性試料の実験代用いた Mn$\mathrm{Bi}$ 化合物は，高周波溶解炉を用い $\mathrm{Mn}$ 之 $\mathrm{Bi}$ の合金を $\mathrm{Ar}$ 気流中で溶解し，直径 $10 \mathrm{~mm} \phi$ の金型に鋳造し，続いて 真空中 $\left(1 \times 10^{-1} \sim 10^{-3} \mathrm{mmHg}\right)$ で $270^{\circ} \mathrm{C}$ の温度で 20 時間熱 処理を行なつた，以上のような方法で作成した化合物を再 び粉碎して，200 mesh 以下の粉末とし，末反応 Mn 拈よ び Bi 索除くため磁気選別を行なつた。

\section{2. 試料作成法}

等方性試料では，上記化合物粉末を成形圧 $5 \mathrm{t} / \mathrm{cm}^{2}$ で直 径 $11.35 \mathrm{~mm} \phi$, 高さ 10 12 $\mathrm{mm}$ の円柱状に成形した。 こ れらの压粉体灾焼結温度 $250^{\circ}, 300^{\circ}, 325^{\circ}, 350^{\circ}, 400^{\circ} \mathrm{C}$ の 温度で各く 3 時間, $A r$ 気流中で焼結を行なつた。

異方性試料で注，Mn-Bi 化合物粉末を0 8 $\mathrm{kOe}$ の磁琞 中で, 成形圧 $5 \mathrm{t} / \mathrm{cm}^{2}$ で成形したのち同様な焼結を真空中 $\left(1 \times 10^{-1} \sim 10^{-3} \mathrm{~mm} \mathrm{Hg}\right)$ で行ない，その磁気特性の改良効 果について実験を試みた。成形は湿式法であり，Mn-Bi 粉 末とエチルアルコールを重量比で約 $3: 1$ の割合にし，磁 界中で磁界响に成形した。

また耐酸化性を向上させる目的で $\mathrm{Mn}-\mathrm{Bi}$ 燒結体の表面 に銅メッキを試みた。すなるち機械的な表面処理をした $\mathrm{Mn}-\mathrm{Bi}$ 焼結体を脱脂したのち強酸中（( $\mathrm{PH}=0.5)$ に数秒間 浸漬する，そして中和後，水洗いしてメッキを行なう。 Table1はメッキ液の組成である。

Table 1 Chemical composition of $\mathrm{Cu}$ plating bath

\begin{tabular}{|c|c|c|}
\hline Composition & Concentration & Reference \\
\hline $\begin{array}{l}\mathrm{CuSO}_{4} \cdot 5 \mathrm{H}_{2} \mathrm{O} \\
\mathrm{NaHCO}_{3} \\
\mathrm{KNaC}_{4} \mathrm{H}_{4} \mathrm{O}_{6} \cdot 4 \mathrm{H}_{2} \mathrm{O}\end{array}$ & $\begin{array}{r}30(\mathrm{~g} / \mathrm{L}) \\
30(\mathrm{~g} / \mathrm{L}) \\
100(\mathrm{~g} / \mathrm{L})\end{array}$ & $\begin{array}{l}\mathrm{PH}: 11.5 \\
\text { Liquid temperature } \\
\qquad 24^{\circ} \mathrm{C}\end{array}$ \\
\hline $\begin{array}{l}\mathrm{NaOH} \\
\mathrm{HCHO}\end{array}$ & $\begin{array}{l}50(\mathrm{~g} / \mathrm{L}) \\
30(\mathrm{cc})\end{array}$ & \\
\hline
\end{tabular}

\section{3. 耐酸 化性 の换討}

$\mathrm{Mn}-\mathrm{Bi}$ 化合物の欠点でする耐食性の覀さを検討するため に $80^{\circ} \mathrm{C}$ 飞保つた恒温槽中に試料を插入し，大気中で0 500 時間放置し(以後は酸化処理と記す)，その磁気特性の 変化を測定した。京な銅メッキをした試料については，酸 化処理前と後の試料をX線マイクロフナライザーにより酸 素の検出を試みあわせて検討した。

\section{III. 実験結果および考察}

\section{1. 焼結による磁気特性}

Fig. 1 は $250^{\circ} \sim 400^{\circ} \mathrm{C}$ の温度範围で各 3 時間， $\mathrm{Ar}$ 気流 中で焼結した等方性試料の磁気特性と焼結温度との関係を 示す. $4 \pi I_{m}, 4 \pi I_{r},{ }_{B} H_{C}$ ともに燒結温度 $350^{\circ} \mathrm{C}$ をで增加

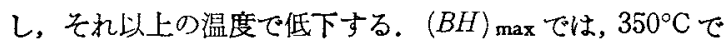
極大值となり $0.8 \mathrm{MG} \cdot \mathrm{Oe}$ 程度である。また ${ }_{I} H_{C}$ は，焼結 


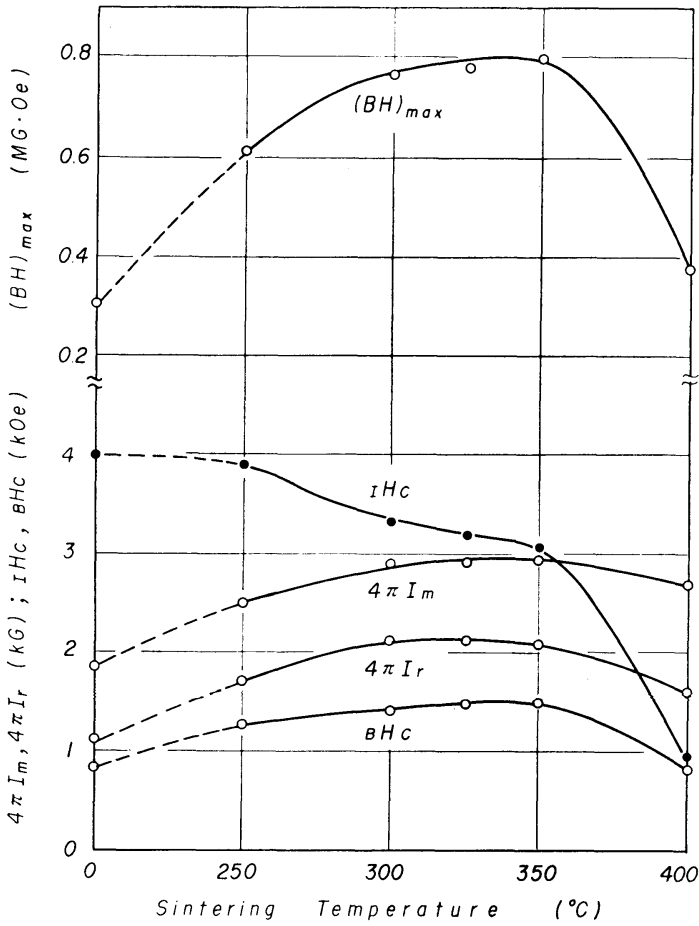

Fig.1 Relation between magnetic properties and sintering temperature of isotropic $\mathrm{Mn}-\mathrm{Bi}$ magnet (Sintering time is $3 \mathrm{hr}$ )

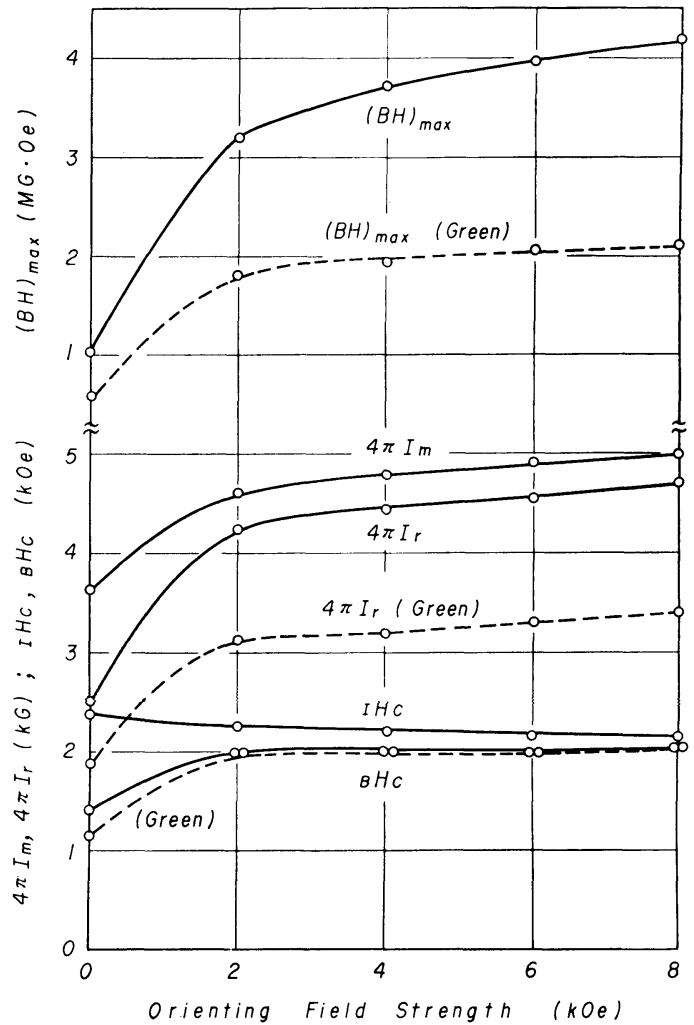

Fig.2 Magnetic properties of sintered $\mathrm{Mn}-\mathrm{Bi}$ specimen as a function of magnetic field applied during pressing (dotted line is Green compact specimen)
温度の上乐にともない減少し てゆく.このことは Photo.1 に示寸各焼結温度に扮ける金 属顕微鏡組織写真により, 高 温度になるほど著しい粒成長 がみられ， $4 \pi I_{m}, 4 \pi I_{r}$ の增 加は焼結過程の進行に対応し ており, ${ }_{I} H_{C}$ の減少は, この 焼結による粒成長に対比する ものと考えられる。

焼結温度 $350^{\circ} \mathrm{C}$ 以上に括け る諸特性の急激な低下，とく に $4 \pi I_{m}$ の低下は, 粒成長以 外の原因も考慮しなければな らない問題であろろ。

2. 異方性試料の 磁気特性

異方性試料に扔いて子等方 性試料と同様に磁気特性は接 結温度に比例して上梨してゆ き， $350^{\circ} \mathrm{C}$ で極大值をとる.

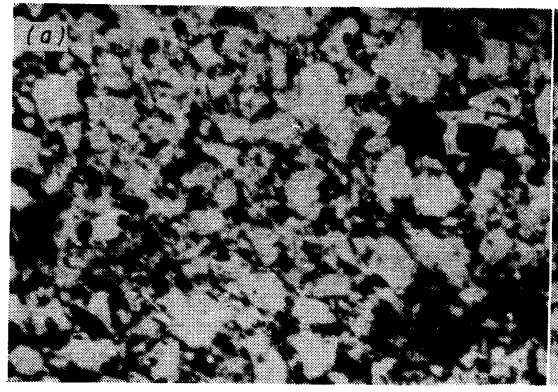

(a) $250^{\circ} \mathrm{C}$

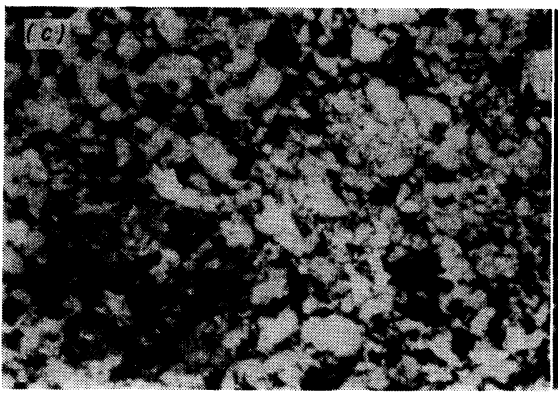

(c) $350^{\circ} \mathrm{C}$

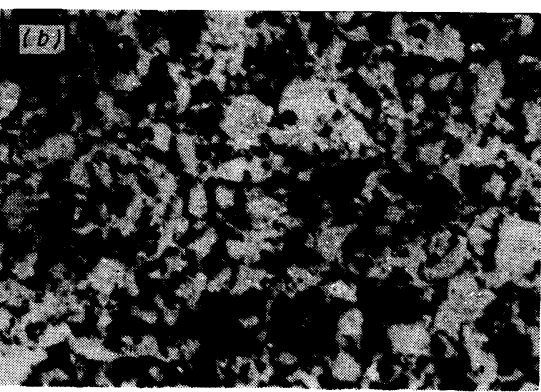

(b) $300^{\circ} \mathrm{C}$

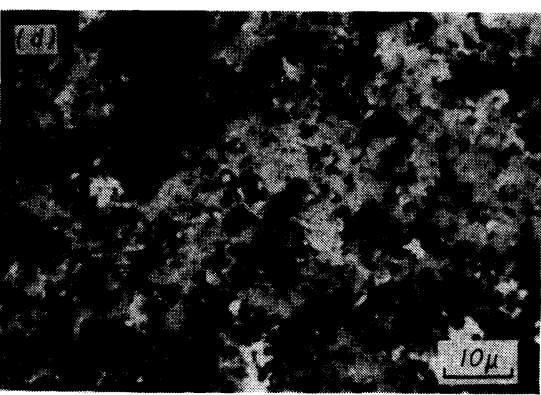

(d) $400^{\circ} \mathrm{C}$
Photo.1 Microstructures of $\mathrm{Mn}-\mathrm{Bi}$ specimens sintered at $250^{\circ}, 300^{\circ}, 350^{\circ}$, $400^{\circ} \mathrm{C}$ for $3 \mathrm{hr}\left(x^{2} / 3\right)$ 
Fig.2は，成形磁界の磁気特性におよぼす影響を示した あのである。成形磁界に比例して諸特性とも増加してい る. 図中 Green の試料と, 焼結試料の ${ }_{B} H_{C}$ では, その差 はほとんどないが，4 $\pi I_{\boldsymbol{r}}$ に拈いては，各成形磁界に拈け る焼結試料とも，Green の試料のそれよりも，約 $40 \%$ 程 度ずつ増大している。 したがつて $(B H)_{\max }$ の值も焼結に より大きく改善される。

Fig.3 に種冬の成形磁界中で $5 \mathrm{t} / \mathrm{cm}^{2}$ の成柇王で成形し

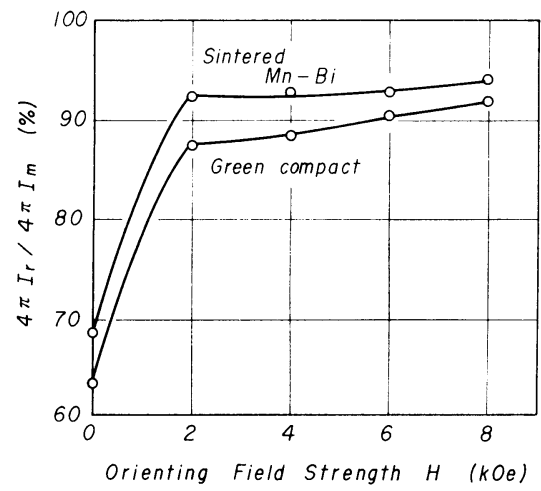

Fig.3 Effect of field strength on $4 \pi I_{r} / 4 \pi I_{m}$ of $\mathrm{Mn}-\mathrm{Bi}$ magnets pressed at $5 \mathrm{t} / \mathrm{cm}^{2}$ and sintered at $350^{\circ} \mathrm{C}$ for $3 \mathrm{hr}$

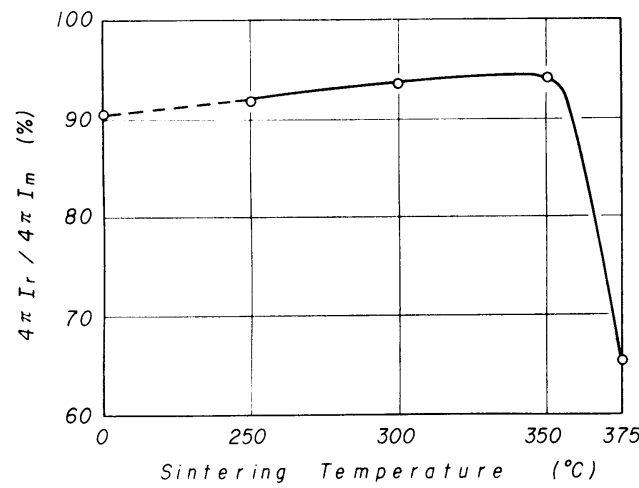

Fig.4 Effect of sintering temperature on $4 \pi I_{r} / 4 \pi I_{m}$ of anisotropic $\mathrm{Mn}-\mathrm{Bi}$ specimen
たものおよびこれを $350^{\circ} \mathrm{C} て ゙ ~ 3 \mathrm{hr}$ 焼結した試料の角型比 と成形磁界の関係を示す. Green 試料でも成形磁界の増大 にともなつて角型比は増加してゆくが, 焼結によつて, よ り顕著となることがわかる.

Fig.4 は, 6000 Oe の磁界中で成形した試料の角型比と 焼結温度の関係を示すが，Green の試料では，約 $90 \%$ の 角型比が得られる，それを焼結した場合， $350^{\circ} \mathrm{C}$ まで増加 してゆき, 約 $94 \%$ 程度となる. $375^{\circ} \mathrm{C}$ では, 角型比は急 激に低下する。

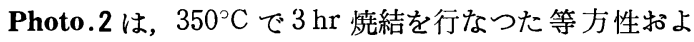
び異方性試料の金属顕微鏡組織写真である．等方性試料で は, 細かな粒子が無秩序に配列していることが観察される が, 異方性試料では, 細長い粒子が整列して成長してい る.これは上述の焼結による $4 \pi I_{m}, 4 \pi I_{r}$ の増大および角 型比の増加と対応するものであり, 焼結により成形磁界の 方向に粒子が成長し, 不規則に配列している細かな粉末が

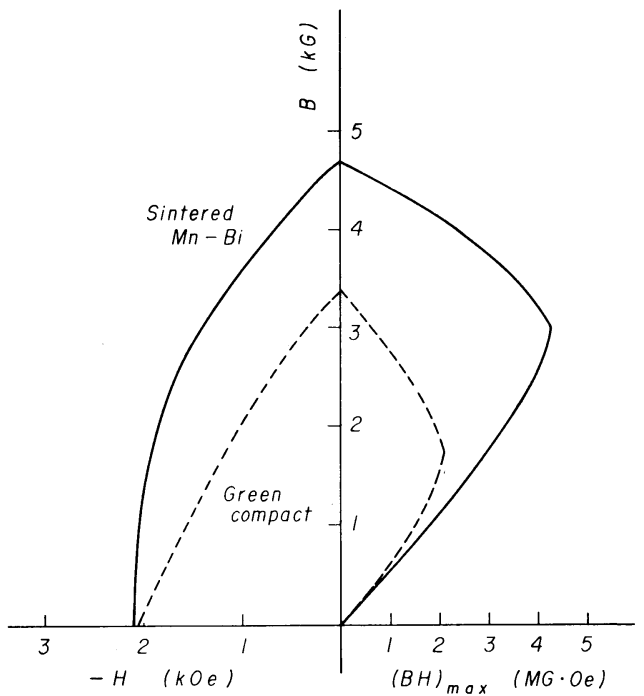

Fig.5 Typical demagnetization curves of anisotropic Mn-Bi magnets

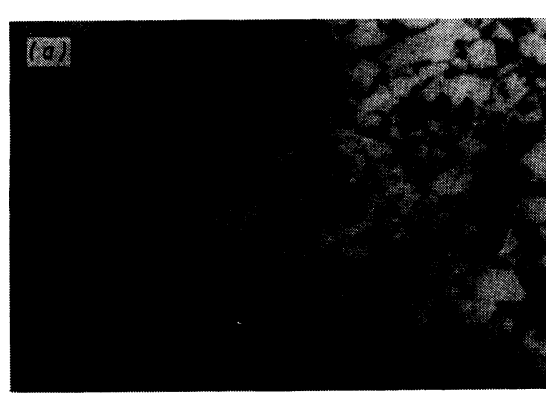

(a) isotropic

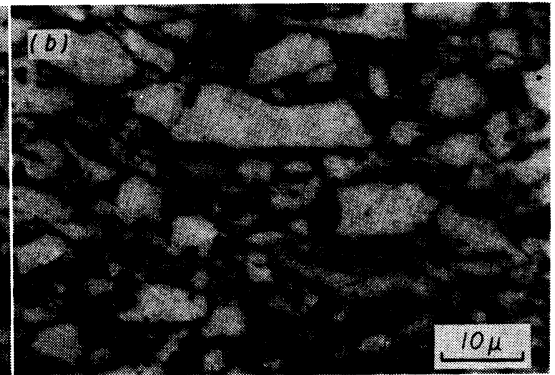

(b) anisotropic

Photo.2 Microstructure of isotropic and anisotropic specimens at $350^{\circ} \mathrm{C}$ for $3 \mathrm{hr}(\times 2 / 3)$

(15) A. L. Stuijts, G. W. Rathenau and G. H. Weber : Philips Teck.Rev., 16 (1954), 141.

これに暒食されること ${ }^{(15)}$, および末反応で混入している $\mathrm{Mn}, \mathrm{Bi}$ がこの焼結により化 合物となり成長してゆくため と思われる。

Fig.5 に本実験で得られた 減磁曲線の一例を示す。

\section{3. 酸化による磁気 特性の变化}

$\mathrm{MnBi}$ 磁石においては耐酸 化の問題が重要であり, 樹脂 中で成形することが試みられている。 また Adams らは 磁性体を黄銅の容器に封ずることを提案している(16). 
事実，压縮成形しただけの試料では，室温に放置しておく と酸化のため 20 ３0 日で崩壊してしまう。また $80^{\circ} \mathrm{C}$ 亿保 つた恒温槽中では，わずか 10 時間前後で酸化されてしま 5.著者らは焼結による耐酸化の効果を実験的に検討した。

Fig.6 は圧縮成形した後，焼結した試料酸化処理を行 なつた場合の $(B H)_{\max }$ の変化および $(B H)_{\max }$ の減少を百

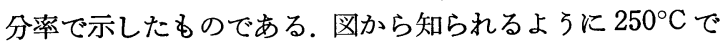
焼結した試料の劣化が非常に顕著である.すなわち酸化処 理前に約 $0.6 \mathrm{MG}$.Oe であつたものが，100 hr を過ぎるこ ろより特性の劣化が激しく, $500 \mathrm{hr}$ 後には $0.3 \mathrm{MG}$. Oe 程 度に減少する。この試料では, $4 \pi I_{m}, 4 \pi I_{r}$ ともに $500 \mathrm{hr}$ 後には，それぞれ約 $30 \%$ 低下し， ${ }_{I} H_{C}$ は幾分増加してい る.このことは, $250^{\circ} \mathrm{C} \times 3 \mathrm{hr}$ の焼結で十分な焼結が行な われないためと思われる. $300^{\circ} \mathrm{C}$ 以上の温度で焼結した試

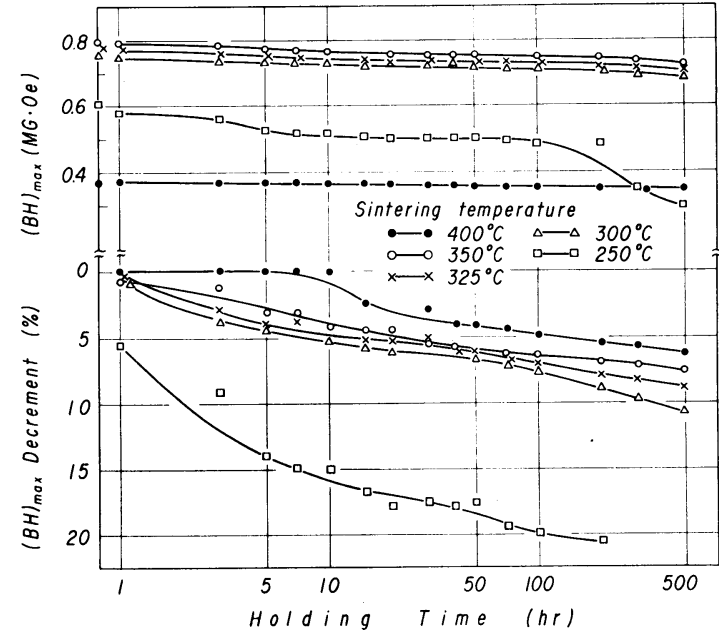

Fig.6 Effect of oxidizing treatment on maximum energy product and its decrement of $\mathrm{Mn}-\mathrm{Bi}$ magnets sintered at various temperatures for $3 \mathrm{hr}$

料では，酸化処理によりこれほど顕著な変化は認められな い.すなわち，燒結温度 $250^{\circ} \mathrm{C}$ の試料が $500 \mathrm{hr}$ 後に $50 \%$ の低下をしている以外は，焼結温度の高い試料ほど耐酸化 性に優れ,いずれの試料も500 hr の酸化処理では, 5 〜 10\% の低下にとどまる。これらはさきに述べた高温度で焼結し た試料ほど粒成長の進行が著しいという結果に対応するる のである.

さらに, Mn-Bi 焼結体を Table 1 亿示す PH : 11.5 の強 アルカリメッキ液中に浸漬し，化学メッキを行ないその表 面に銅層を堆積させることにより耐酸化性の向上を試み た.

メッキ時間と銅の析出量との関係は, ほ湆比例関係にあ り，メッキ時間 20 分では $30 \mu$ 以上の銅層が作られる。こ れらの銅層の厚さはX.M.A. による測定と金属顕微鏡組

(16) E.Adams : Conf. Mognetic Materials, Boston 1956, AIEE (1957) .
織写真を併用して決定した。メッキ時間と磁気特性，銅層 の磁性体表面への堆積量の関係を Fig.7 に示す．銅層の 堆積により $4 \pi I_{r}$ がいくぶん減少し， $(B H)_{\max }$ もやや低 下するが ${ }_{I} H_{C}$ がわずか増大する.

これらの試料に酸化処理をすると, 銅層の厚さが $30 \mu$ 以 上あるものは, Fig.8 に示すよ5に $500 \mathrm{hr}$ の酸化処理後 あ核とんぞ磁気特性に変化は認められず，完全に酸化防止 の目的を達している(17).

これらの銅層 $30 \mu$ 以上の試料をX.M.A.により, 試料 の中心より外側に向つて scanning させ, $\mathrm{Cu}, \mathrm{Mn}, \mathrm{Bi}$ の場 所的分布を測定した. Fig.9 はこの結果である.これよりマ ンガソおよびビスマスについては，末反応の金属 $\mathrm{Mn}, \mathrm{Bi}$ の残留が観察される．また酸素の検出に関しては，酸化好 理前後の試料はともにほとんど同様な傾向にある。すなわ

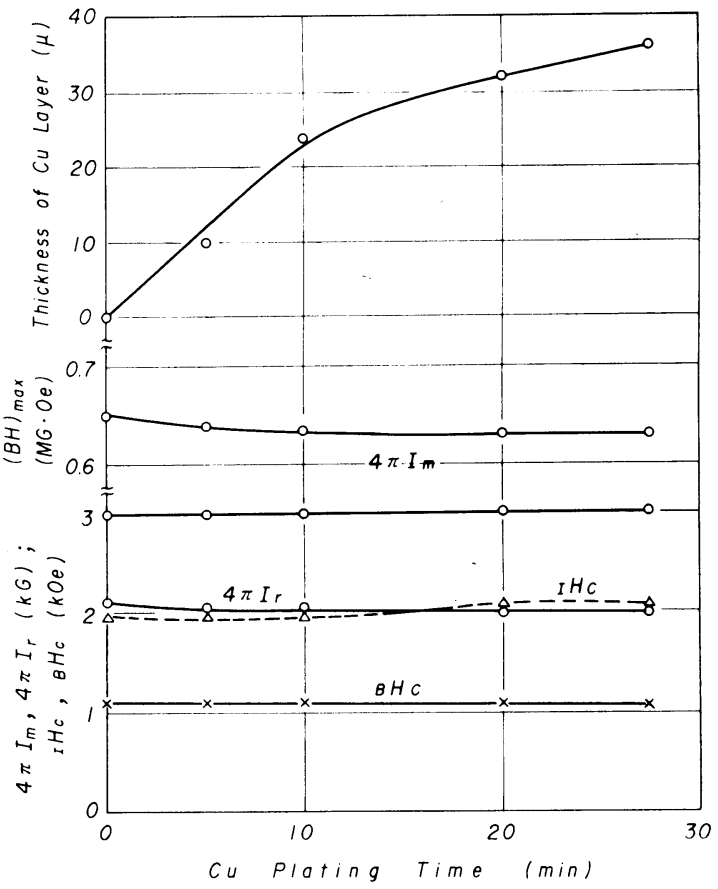

Fig.7 Effect of $\mathrm{Cu}$ plating time on magnetic prcperties of isotropic $\mathrm{Mn}-\mathrm{Bi}$ magnet and on thickness of $\mathrm{Cu}$ layer

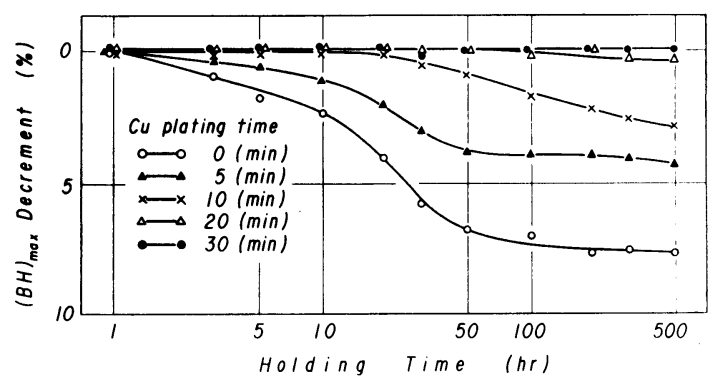

Fig. 8 Relation between oxidizing treatment and maximum energy product decrement

（17）特許公報：昭和 42-11134 参照 


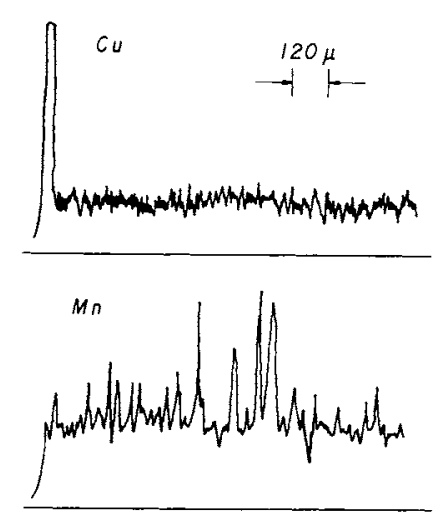

$B i$

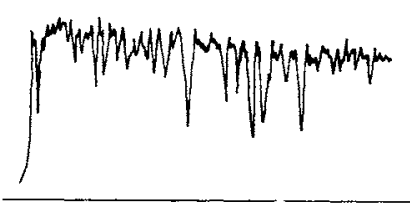

Fig.9 X-ray microanalysis of sintered and $\mathrm{Cu}$ plated $\mathrm{Mn}-\mathrm{Bi}$ specimens

ち, いずれの場合も $O_{K \alpha}$ の intensity がその back ground の範囲内でありとくに酸素の intensityが大である点は 観察されていない.

\section{IV. 総括}

粉末治金法による Mn-Bi 乐磁石の実験結果を総括すれ ば以下のようである。
(1) Mn-Bi 系化合物を圧粉して，焼結することによる磁 気特性の改良効果は蹎著である。等方性試料では，暁結温 度 $350^{\circ} \mathrm{C}$ て磁気特性は極大值をとり，(BH) $\max$ は $0.8 〜$ $1.0 \mathrm{MG} \cdot \mathrm{Oe}$ である. 異方性試料でるこの傾向は，まつたく 同じであるが，磁気特珄におよぼす焼結の影響はさらに大 きい.すなわち， $4 \pi I_{m}, 4 \pi I_{r},(B H)_{\max }$ などの增大扣よ び角型比の向上が明瞭にみられ，また顕微鏡的にる焼結に より磁界の方向に粒子の成長が顕著である．これは試料中 の多少力向のずれた粒子がこれら方向性のよい粒子に龺食 され，また末反応 $\mathrm{Mn}, \mathrm{Bi}$ が反応し化合物となるための磁 気特性の向上であると思われる。

本実験で焼結温度 $350^{\circ} \mathrm{C}$, 成形压 $5 \mathrm{t} / \mathrm{cm}^{2}$, 成形磁界 8000 Oeの条件では，下記のような値が得られている.

$$
\begin{aligned}
& 4 \pi I_{r}: 4400 \sim 4700(\mathrm{G}) \quad{ }_{B} H_{C}: 2100 \sim 2800(\mathrm{Oe}) \\
& (B H)_{\max }: 4.1 \sim 4.6(\mathrm{MG} \cdot \mathrm{Oe})
\end{aligned}
$$

(2) 耐酸化珄に扔いても焼結の効果恃大である。焼結温 度の上昇にとすな，粒成長が観察され耐酸化性は向上す る.とくに磁気特性との兼就合いより $350^{\circ} \mathrm{C}$ 焼結が適当で あると思われる。

（3）銅メッキの場合，試料をメッキ液に浸漬する時間と 銅の試料表面への堆積量は，活添比例する。

焼結 $\mathrm{Mn}-\mathrm{Bi}$ 磁石の表面飞 $30 \mu$ 以上の銅層を唯積すれ ば，完全に酸化を防止できることが確認された。 